\begin{tabular}{|c|c|c|c|}
\hline Article Info & RESEARCH ARTICLE & ARAŞTIRMA MAKALESİ & \\
\hline Title of Article & $\begin{array}{r}\text { Examining of Urba } \\
\text { Through Ankara Bey } \\
\text { the Framework of } \mathrm{H} \\
\text { Cor }\end{array}$ & $\begin{array}{l}1 \text { Lighting Elements } \\
\text { azar Example Within } \\
\text { man Oriented Design } \\
\text { cept }\end{array}$ & \\
\hline $\begin{array}{l}\text { Corresponding } \\
\text { Author }\end{array}$ & \multicolumn{2}{|c|}{$\begin{array}{l}\text { Doç. Dr. Cem DOĞAN } \\
\text { Mimar Sinan Güzel Sanatlar Üniversitesi / Fen Bilimleri Enstitüsü / İç Mimarlık Anabilim } \\
\text { Dalı, cem.dogan@msgsu.edu.tr }\end{array}$} & \\
\hline $\begin{array}{l}\text { Received Date } \\
\text { Accepted Date }\end{array}$ & \multicolumn{2}{|c|}{$\begin{array}{ll}03.01 .2021 \\
09.03 .2021\end{array}$} & \\
\hline Author / Authors & $\begin{array}{l}\text { Doç. Dr. Cem DOĞAN } \\
\text { Bade KANATLI }\end{array}$ & $\begin{array}{l}\text { ORCID: 0000-0003-0356-1324 } \\
\text { ORCID: 0000-0001-8851-5719 }\end{array}$ & \\
\hline How to Cite & \multicolumn{2}{|c|}{$\begin{array}{l}\text { Doğan, C. \& Kanatlı, B. (2021). Kentsel Aydınlatma Elemanlarının İnsan Odaklı } \\
\text { Tasarım Kavramı Çerçevesinde Ankara Beypazarı Örneği Üzerinden İncelenmesi. } \\
\text { Kent Akademisi, Volume, 14, Issue 1, Pages 141-155. }\end{array}$} & $\begin{array}{l}\text { Kent Akademisi } \\
\text { Urban Academy }\end{array}$ \\
\hline
\end{tabular}

\title{
Kentsel Aydınlatma Elemanlarının İnsan Odaklı Tasarım Kavramı Çerçevesinde Ankara Beypazarı Örneği Üzerinden İncelenmesi
}

\begin{abstract}
:
Cities are areas where social life continues and cultural heritage is exhibited. It is possible to clearly see the cultural heritage of the region in the historical city squares. In the context of the city, it is very important to meet the needs of people and to ensure the continuity of the movement of people in social life at night as well as during the day. The most important element that makes the historical area visible at night and ensures the continuity of human movement in the city is the lighting elements that are urban furniture. Lighting elements should be positioned and designed in a correct planning framework. A correct planning is only possible with an understanding that puts the people living in the city and the guests coming to the city at the center of the design. Therefore, it is thought that the correct result will be achieved when urban lighting is interpreted within the framework of the human-oriented design concept. Maslow's Hierarchy of Needs theory, which is still accepted today, focuses on human and reveals human needs based on biological and environmental factors. In this context, when we consider Maslow's Hierarchy of Needs theory as a principle for human-oriented urban lighting planning, it is thought that the planning and design will turn into a successful urban furniture system. In addition, in this study, in the literature review, studies on urban lighting elements, urban lighting master plan schemes and human-oriented design were scanned, case studies were made in obtaining research data and this study was analyzed with appearance diagrams showing the night illumination through the Ankara Beypazarı Area lighting plans, and it was compared with Maslow's Hierarchy of Needs pyramid criteria to show that the results were obtained.
\end{abstract}

${ }^{1}$ Mimar Sinan Güzel Sanatlar Üniversitesi, Fen Bilimleri Enstitüsü, İç Mimarlık Anabilim Dalı, cem.dogan@msgsu.edu.tr

${ }^{2}$ Mimar Sinan Güzel Sanatlar Üniversitesi, Fen Bilimleri Enstitüsü, İç Mimarlık Anabilim Dalı, badekanatli@ hotmail.com 
ÖZ:

Kentler, sosyal yaşamın devam ettiği ve kültürel mirasın sergilendiği alanlardır. Tarihi kent meydanlarında, bölgenin kültürel mirasını açıkça görmek mümkündür. Kent bağlamında insanın ihtiyaçlarını karşılamak ve gündüz gibi gece de insanın sosyal hayattaki hareketinin devamlılığını sağlamak oldukça önemlidir. Tarihi bölgeyi gece görünür kılan ve kent içerisinde insan hareketinin devamlılığını sağlayan en önemli unsur, kent mobilyası olan aydınlatma elemanlarıdır. Aydınlatma elemanları, doğru bir planlama çerçevesinde konumlandırılmış ve tasarlanmış olmalıdır. Doğru bir planlama ancak, kentte yaşayan insanları ve kente gelen misafirleri tasarımın odağına alan bir anlayış ile mümkündür. Dolayısıyla, kent aydınlatmalarının insan odaklı tasarım kavramı çerçevesinde yorumlandığı zaman doğru sonuca ulaşılacağı düşünülmektedir. Günümüzde halen kabul görmekte olan Maslow'un İhtiyaçlar Hiyerarşisi kuramı, insanı odağına almakta ve insanın biyolojik ve çevresel faktörlere dayanan ihtiyaçlarını ortaya koymaktadır. Bu bağlamda, Maslow'un İhtiyaçlar Hiyerarşisi kuramını, insan odaklı kent aydınlatma planlaması için bir ilke olarak ele aldığımızda ortaya çıkacak planlamanın ve tasarımın başarılı bir kent mobilyası sistemine dönüşeceği düşünülmektedir. Ayıca bu çalışmada, alan yazın taramasında kentsel aydınlatma elemanları, kent aydınlatma master plan şemaları ve insan odaklı tasarım konulu çalışmaların tarandığı, araştırma verilerinin elde edilmesinde örnek olay incelemesi yapıldığı ve bu incelemenin Ankara Beypazarı Bölgesi aydınlatma planları üzerinden gece aydınlatma durumunu gösteren görünüş diyagramları ile analiz edilip, Maslow'un İhtiyaçlar Hiyerarşisi piramidi ölçütleri ile karşılaştırılarak sonuç bulguların elde edildiği ortaya konulmaya çalışılmıştır.

ANAHTAR KELIMELER: Tarihi Kent Meydanları, Kent Mobilyası, Kentsel Aydınlatma Elemanı, İnsan Odaklı Tasarım

\section{"Kentsel Aydınlatma Elemanlarının İnsan Odakı Tasarım Kavramı Çerçevesinde Ankara Beypazarı Örneği Üzerinden İncelenmesi”}

\section{GíRiş:}

Uzun süreler boyunca insan, doğal ışığa bağlı kalarak yaşamıştır. Ateşin bulunması ile birlikte, ilk yapay ışık kaynağı ortaya çıkmıştır. Ateş, evlerde kullanılmaya uygun bir ısınma ve aydınlatma aracı olduğundan dolayı gecenin karanlığını, evlerin pencerelerinden sızan ışık aydınlatmaya başlamıştır. İlkel aydınlatma elemanı olan çıralar ve mumlar, insana sokak ve meydanlardaki hareketi esnasında yol gösterici olmuştur. Ancak, gecenin karanlığında uzun süre kalabilmek için ateşi daha uzun süre muhafaza etme ihtiyacı doğmuştur. Bu ihtiyaç ise, kandil ve fenerler ile sağlanmıştır. Bu şekilde geceyi aydınlatmak en ilkel haliyle başlamıştır (Aydın, 2015: 10-23). 18. yüzyılın sonlarında elektriğin bulunması ile sokaklar aydınlatılmaya başlanmışıı. Dünyada elektrik ile aydınlatılan ilk cadde Fransa'nın Lyon kentindeki Imperiale Caddesi'dir. Bunu Paris'teki Opera Caddesi takip etmektedir. Ülkemizde ise, 19. yüzyılın başlarında ilk defa Tarsus'ta elektrik üretilmiş ve Tarsus sokakları aydınlatılmıştır (Kılıç Sirel, 2016).

Tarihi kent meydanları; kent kültürünün önemli bir parçasını oluşturan, kentin kimliğini ve tarihsel sürecini bize aktaran en önemli kamusal alanlardır (Özer ve Ayten, 2005: 96). Kentlerdeki nüfus artışları ve kentlerin gelişimiyle birlikte iç mekânda olduğu gibi kamusal alanlarda da işlevsel elemanlara ihtiyaç duyulmaya başlanmıştır. 19. yüzyılın ortalarında İngiltere'de kent mobilyası kavramı ortaya atılmıştır (Küçükkılıç, 2008:2).

Kent mobilyaları, bulunduğu bölgeye ve kültüre göre değişiklik gösterecek olan kentin donatı elemanlarıdır. Kentlinin sosyal, kültürel ve ekonomik gereksinimlerini karşllarken, kent içi hareketlerini kolaylaştıran ürünlerdir (Güneş, 2005: 92; Düzenli ve ark., 2017: 479).

Kentsel aydınlatma elemanı, ilk olarak Romalılar döneminde karşımıza çıkmaktadır. Yağ lambalarıyla kullanılan aydınlatma direkleri dönemin işlevsel kent mobilyalarıdır. Işık kaynaklarının ve aydınlatma elemanlarının da gelişimiyle eş zamanlıdır. Kentlerdeki sosyal yaşamın artması ile aydınlatma elemanlarının önemi artmışıtır. Sadece işlevsel açıdan değil aynı zamanda estetik açıdan da aydınlatmaya ve aydınlatma elemanlarına ihtiyaç duyulmuştur (Küçükkılıç, 2008:2-14). Kent aydınlatması, tarihte olduğu gibi insan hareketinin gece de kesintisiz devam etmesini aynı zamanda güvenlik ve emniyetin sağlanmasını amaçlamaktadır. Ayrıca insanın gece karanlığında kenti anlamasını ve tanımasını sağlayan en önemli unsurdur. (Özenç ve Menteşeoğlu, 2013: 69). Tarihsel süreci incelediğimizde, 
aydınlatmanın ortaya çıkışı ve geliştirilmesi ile başlayan süreç, sokak ve kentlerin aydınlatılması, aynı zamanda kentsel değer olan aydınlatma elemanlarının bugüne kadar gelişiminin tamamı insan ihtiyaçları doğrultusundadır.

İhtiyaçlar hiyerarşisi; Amerikalı Psikolog Abraham Maslow tarafından, insanın temel ihtiyaçlarını ortaya koyan kuramdır. İnsan, yaşam boyu temel ihtiyaçlara sahiptir ve bu ihtiyaçların düzenli olarak giderilmesi gerekmektedir. İhtiyaçların en temeli olan barınma, uyuma, hareket etme gibi fizyolojik ihtiyaçları, güvenlik ve emniyet ihtiyaçları takip etmektedir. $\mathrm{Bu}$ iki ana ihtiyaç, piramidin en altında bulunur ve giderilmediği takdirde diğer üst düzey ihtiyaçların, ihtiyaç olarak algılanmamasına sebep olmaktadır (Maslow 1954: 59-75; Walsh, 2011:579). Temel ihtiyaçların karşılanması durumda ise, insanda diğer istekler ortaya çıkmaktadır. Bunlar; ait olma, idrak etme ve estetik gereksinimlerdir.

İnsan odaklı tasarım; kullanıcıların ihtiyaç ve gereksinimlerini merkeze alarak ürün veya sistemleri daha kullanışlı hale getirmeyi amaçlayan bir yaklaşımdır. Bu yaklaşım ürün verimliliğini, insan refahını, kullanıcı memnuniyetini artırdığı gibi sürdürülebilirliği de geliştirmektedir. Aynı zamanda, insan sağlığı, güvenliği ve performansı üzerindeki olası olumsuz etkileri önler. İnsan odaklı tasarım ilkeleri bugün dahi önemli ölçüde değişiklik göstermemektedir (ISO 9241-210:2010:4).

Çalışmanın problem tanımı: Tarihi bölgelerdeki bir kent mobilyası olan aydınlatma elemanlarının, insan odaklı tasarım kavramı çerçevesinde incelendiğinde; tarihi değerleri yansıtmadığı, bölge kullanıcılarının ihtiyaçları doğrultusunda seçilmediği ve konumlandırılmadığı gözlemlenmektedir.

Çalışmanın amacı: Tarihi bölgedeki kentsel aydınlatma elemanlarının, Maslow’un İhtiyaçlar Hiyerarşisi kuramı kapsamında insan odaklı tasarım kavramı çerçevesinde incelenmesi amaçlanmıştır.

Hipotez: Kentsel aydınlatma elemanlarının insan odaklı tasarım kavramı çerçevesinde yeniden düzenlendiğinde, kente ve kullanıcıya olumlu etkileri görülmektedir.

Çalışmanın kapsamı: Maslow'un İhtiyaçlar Hiyerarşisi kuramı kapsamındaki ana maddeler, tarihi Ankara Beypazarı bölgesindeki aydınlatma elemanları üzerinden incelenmiştir.

\section{Literatür Taraması}

Literatürde bilimsel kelimelerimizden olan; tarihi kent meydanları, kent mobilyası, kentsel aydınlatma elemanı, insan odaklı tasarım kavramları araştırılmış ve yapılan çalışmalar Tablo 1'de özetlenmiştir.

\begin{tabular}{l|l}
\multicolumn{1}{|l}{ Yazar } & \multicolumn{2}{l}{ Konu } \\
\hline $\begin{array}{l}\text { Özmer ve Sümengen, } \\
(2019)\end{array}$ & $\begin{array}{l}\text { Kültür Varlıklarının Dönüşümü ile } \\
\text { Sokak Ölçeğinde Aydınlatma Tasarımı } \\
\text { Değerlendirmesi: Kayseri-Ali Saip } \\
\text { Paşa Sokağı }\end{array}$ \\
\hline
\end{tabular}

Köseli ve Yener,

(2019)

Akkaya, (2019)

Düzenli, Yılmaz ve Peyzaj Mimarlı̆̆ı Eğitiminde Donatı-

İnsan Odaklı Aydınlatma Tasarım Konsepti: Ofis İç Mekânı İçin Bir Öneri Mekân Algisı Üzerine Etkileri

\section{Amaç}

Doğru bir aydınlatma tasarımı ve kullanılan aydınlatma elemanlarının bölgenin tarihsel sürecini yansıtacak şekilde tasarlanması veya yenilenmesi gerektiğini Kayseri-Ali Saip Paşa Sokağı örneği üzerinden açıklanmıştır.

Bir ofis ortamında, yeni bir aydınlatma tasarım konsepti olan, "Insan Odaklı Aydınlatma (Human Centric Lighting-HCL)" çerçevesinde, aydınlatma tasarımının önemine işaret edilmekte ve bu konseptin, mekânlara nasıl uygulanacağını göstermek amaçlanmaktadır.

Kentsel Tasarım Kapsamında Zamanın Kentsel mekânların zaman-mekân algısı ile birlikte, insan hareketi ve deneyimleri ile şekillendiği ortaya konulmaktadır.

Öğrencilere mekân tasarlamayı öğretirken, 
Özkan, (2017)

Küçük, (2014)

Çağlayan, Özturan, ve Erten Bilgiç, (2014).

Özenç ve Menteşeoğlu, (2013).

Küçükkılıç, (2008)

Genamaz, (2008)

Onuk, (2008)

Şerefhanoğlu Sözen, (2005).
Mekân İliş̧kisinin Kurgulanması

Kentsel Aydınlatmada, Aydınlatma Master Planları ve Aydınlatma Master Planı İçin Bir Rehber Önerisi

Kent Meydanı Yapay Aydınlatması Kriterleri

İzmir'deki Kent Aydınlatmasına Yönelik Olumsuz Uygulamalar ve Çözüm Önerileri

Kent Mobilyası Olarak Aydınlatma Elemanları - Boğaziçi'nden Örnek İncelemeler

Kentsel Mekân Algsında Yapay Aydınlatmanın Kullanılması ve Kent İmajı ile İlişkilendirilmesi

Kentsel Dış Mekânların Aydınlatılması Kapsamında Işık Kirliliğinin İrdelenmesi

Kent Güzelleştirme ve Aydınlatma Master Planı kullanıcı istek ve ihtiyaçları doğrultusunda mekân ve donatı elemanları üzerinden yaşanabilir mekânlar oluşturmak amaçlamıştır.

Kent bağlamında, yapılan araştırmalar ve analizler ile birlikte, doğru ve etkili bir aydınlatma master plan rehberi oluşturulması amaçlanmıştır.

Kent meydanlarında yapay aydınlatma uygulanırken, dikkat edilmesi gereken kriterlerin belirlenmesi ve bu kriterler doğrultusunda, yapılacak diğer çalışmalar için bir rehber oluşturulmaya çalışılmıştır.

Kent aydınlatmaları, teknik ve estetik yönlerine vurgu yapan master planlar çerçevesinde ortaya konmalı veya değerlendirilmedir. Bu bağlamda, çalışmada İzmir 'deki kent aydınlatmaları çevresindeki tüm öğeler dikkate alınarak bir çözüm önerisi ortaya konulmaktadır.

Kent mobilyalarından biri olan aydınlatma elemanlarının; kent kimliği, tarihi çevre ile uyumu, 1şık kirliliği, etkin enerji kullanımı ve estetik değerler açısından Boğaziçi bölgesi meydanları üzerinden incelenmesi amaçlanmıştır.

Kentsel aydınlatma tasarım sürecinin, kentsel mekânlarda gece aktiviteleri üzerinde etkili olabilecek değişkenleri tanımlayarak bir analiz oluşturmak, Beyoğlu bölgesinin dinamik yapısı üzerinde incelenmesi amaçlanmıştır.

Yanlış kent aydınlatma uygulamları sonucu ortaya çıkan 1şık kirliliği kavramının, örnek alanlar (Ulus parkı, Taksim Meydanı, İstiklal Caddesi) üzerinden incelenmesi ve doğru önerinin getirilmesi amaçlanmıştır.

Şehirlerin güzelleşmesinde etkin rolü olan aydınlatma elemanlarının, teknik yönden incelenmesi ve bir master plan bağlı kalması gerektiğini Şerefhanoğlu Sözen, ortaya koyduğu bir master plan çerçevesinde anlatmayı amaçlanmıştır.

Tablo 1: Tarihi Kent Meydanları, Kent Mobilyası, Kentsel Aydınlatma Elemanı, İnsan Odaklı Tasarım konularını kapsayan çalışmalar (Bade Kanatlı ve Cem Doğan tarafından hazırlanmıştır.)

\section{Maslow’un İhtiyaçlar Hiyerarşisi Kapsamında Kent Aydınlatmasının Önemi ve Aşamaları}


Işık, görsel algıyı mümkün kılan bir unsur olmanın yanı sıra insanı psikolojik ve fizyolojik yönden etkileyen bir öğedir. Bulunduğumuz ortamda çevreyi görmemizi sağlayan ışık, aynı zamanda insanın hormon seviyesini ve ruh halini etkilemektedir. Doğru ve yeterli kullanılan ışık, insan sağlığına ve yaşam kalitesine katkıda bulunmaktadır.

Corten'a göre; kent aydınlatması, kenti yaşayan ve deneyimleyen kişilerin yaşam kalitesini ve orada bulunma sürelerini arttırmada, kent mekânlarının görünür kılınmasında en önemli araçlardan biri olmaktadır. Ayrıca kentsel mekânların iyileştirilmesinde önemli bir araç olduğunun altı çizilmektedir. Kent mekânlarının iyileştirilmesi için; güvenlik ve emniyet, anlaşılabilir ve görünür olması, mekânsal hafıza, mekânların anlamlandırılması şeklinde ana temalar ortaya konmaktadır (Aktaran: Küçük, 2014:5).

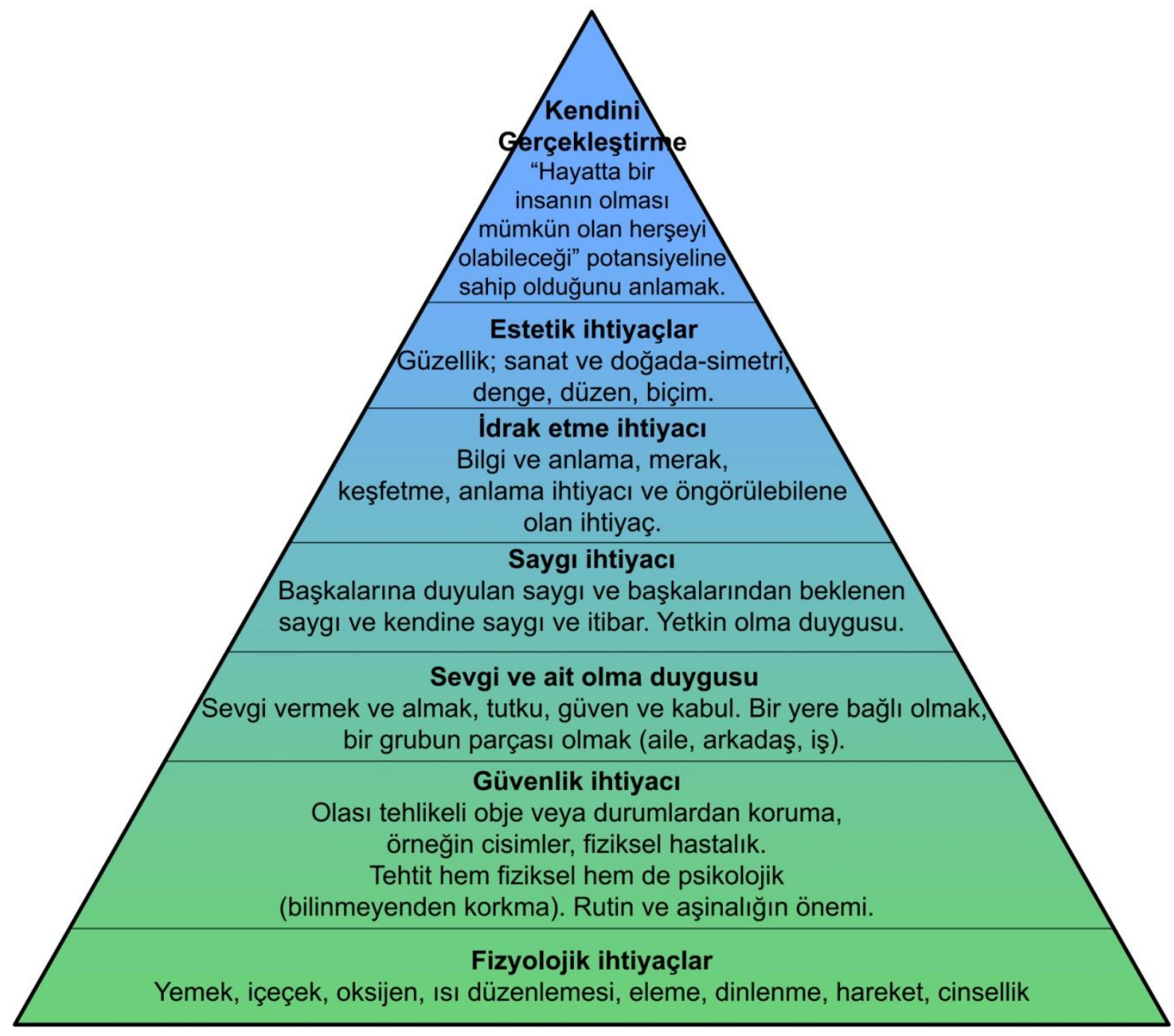

Şekil 1: Maslow’un İhtiyaçlar Hiyerarşisi Piramidi (Degiorgio, 2014: 57).

İnsanın fizyolojik ihtiyaçlardan başlayarak bir birey olmaya yani insanın kendini geliştirmeye yönelik sürecini "Maslow'un İhtiyaçlar Hiyerarşisi" çerçevesinde inceleyecek olursak, iyi bir kent aydınlatması için ihtiyacımız olan maddeleri görmek mümkündür. İnsanın fizyolojik ihtiyaçları, güven, aitlik duygusu, kolay anlama, idrak etme ve merak duygusu, estetik açıdan denge, simetri ve biçim gibi insani ihtiyaçlar, bir kent aydınlatma çalışması sırasında bize 1şık olacak maddeleri oluşmaktadır (Maslow, 1954: 59-75; Degiorgio, 2014: 57).

\subsection{Fizyolojik İhtiyaçlar}

Kentsel Aydınlatma Elemanlarının İnsan Odaklı Tasarım Kavramı Çerçevesinde Ankara Beypazarı Örneği Üzerinden İncelenmesi

Journal of Urban Academy | Volume: 14 Issue: 1 | ISSN: 2146-9229 
Fizyolojik gereksinimler, insan yaşamının devamı için mutlaka karşılanması gereken ihtiyaçlardır. Açlık, susuzluk, barınma, uyuma, hareket etmek gibi temel ihtiyaçların eksikliği, insana fizyolojik ve psikolojik açıdan etki etmektedir. Çünkü bu temel gereksinimler, insanın biyolojik yapısının bir parçasını oluşturmaktadır. Eğer insan temel ihtiyaçlarını düzenli olarak karşılarsa, diğer ihtiyaçlarını doğru bir şekilde belirleyebilmektedir (Maslow, 1962:162-165). Gece karanlığında insan hareketi için 1şığın kaçınılmaz olduğunu söyleyebiliriz. Bu durumda kentlerin aydınlatılması insan hareketi için önemli bir konudur. Doğru ve yeterli bir kent aydınlatması, insan hareketinin gündüz olduğu gibi gecede devam etmesini sağlamaktadır. Kenti aydınlatan ışık, insan hareketini doğrudan etkilediği için fizyolojik ihtiyaçların karşılanması yönünden kent aydınlatmaları oldukça önemli bir yere sahiptir.

\subsection{Güvenlik İhtiyacı}

İnsanın temel ihtiyaçlarından biri de güven duygusudur. Yapılan çeşitli araştırmalarda karanlık, insanda endişe ve korku hisleri uyandırmaktadır. Dolayısıyla insan 1şığın olmadığı ortamlarda bulunmak istemez. Kenti gecenin karanlığında güvende tutmak için aydınlatma elemanlarına ihtiyaç duyulmaktadır. 1960'lardan bu yana kentlerde güvenlik ve fonksiyonel amaçlarla kullanılan aydınlatmalar, kent emniyeti için önem taşımaktadır (Bertin, 2015). Aydınlatma elemanları; kentsel alanların korunmasına, kenti otomobil ve yayalar için erişilebilir hale getirilmesine yönelik işlevsel bir amaca sahiptir.

\subsection{Ait Olma Duygusu}

İnsandaki ait olma duygusu kişinin kendisi ile değil, çevresi ile ilgilidir. Bu duygu, içerisinde sevgi ve saygıyı barındırmaktadır. Bir yere ait olmak başkaları ile iletişim kurmayı ve insanlar tarafından kabul edilmeyi beraberinde getirmektedir (Maslow, 1962: 26). Dolayısıyla insanın çevresindeki kişiler ve yaşadığı mekânlar önemlidir. İnsan kendini yaşadığı kentte yabancı hissetmemelidir. Her kentin bir hikâyesi vardır. Aydınlatma elemanları, bu hikâyeyi gece ortaya çıkaran ve insanların ait olma duygusu üzerinde etkisi olan en önemli kent mobilyalarıdır. Maslow’a göre; eğer ait olma duygusu insanda eksik kalır ise, ihtiyaçlar piramidi üzerinde bir sonraki basamağa geçmek mümkün olmayacaktır.

\section{4. İdrak Etme İhtiyacı}

İnsanın yaşadığı kenti idrak edebilmesi için; görünür, okunaklı ve anlaşılabilir olması gerekmektedir. Kenti bütün olarak ele aldığımız zaman dinamik bir yapıya sahip olduğunu görebiliriz. Dolayısıyla karmaşık bir sistem üzerine kurulu olan kent, gündüz olduğu gibi gece de insanların vakit geçirip, kentin kimliğini ve tarihi dokusunu algılayabilmeleri açısından kent aydınlatmaları oldukça önemli bir yere sahiptir (Lynch, 1960: 3-14). Kentin aydınlatılmasında, doğru ve yeterli aydınlatma elemanlarının kullanılması halinde ise, kenti ilk defa deneyimleyecek olan misafirler açısından kent kolay anlaşılabilir ve okunabilir olacağı için yer-yön bulmayı ve kenti rahat bir şekilde deneyimlemeyi sağlayacaktır.

\subsection{Estetik İhtiyaçlar}

Kent aydınlatmalarının, güvenlik ve fonksiyonel amaçlarına ek olarak, 1989 yılından sonra aydınlatma planlarıyla kentin tarihi dokusu da göz önünde bulundurularak, işlevsel amacın yanı sıra estetik açıdan da incelenmeye başlanmış ve kent kimliği gecenin karanlığına yansıtılması amaçlanmıştır (Narboni, 2004: 66). Ayrıca 1şığın estetik yönleri göz önüne alınarak yapılan şehir stratejileri, gece karanlığında şehir manzaraları oluşturmak ve düzenlemek amacı ile aydınlatma planları geliştirilmeye başlanmıştır. Her kentin kendine özgü tarihi dokusu ve mimarisi vardır. Dolayısıyla kent kültürünü tanıtmak ve vurgulamak için aydınlatmaya ihtiyaç duyulmaktadır. Gün boyunca görünmeyen detayları gecenin karanlığında ortaya çıkarıp, kusur olarak görünen öğe veya mekânları doğru aydınlatma ile gizlenebilir ve böylece kentin algısı değiştirilebilir olduğunun altı çizilmiştir (Fiori ve Regnault, 2007: 19-21). Kent aydınlatması estetik yönden ele alındığında kent kimliği ve kent hafızası için önemli bir unsurdur. Ayrıca aydınlatma elemanlarının kentin aksesuarı olduğu unutulmamalıdır. Bu bağlamda aydınlatma, estetik yönden kente değer katmaktadır.

\section{Kent Analizi ve Aydınlatma Master Planı}

Kentsel Aydınlatma Elemanlarının İnsan Odaklı Tasarım Kavramı Çerçevesinde Ankara Beypazarı Örneği Üzerinden İncelenmesi

Journal of Urban Academy | Volume: 14 Issue: 1 | ISSN: 2146-9229

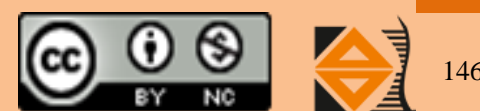


Aydınlatma planlarının ortaya çıkması kentin yaşadığı dönemi ve kent mirasını ortaya koymaya yardımcı olan bir araçtır. Kent ve kent meydanlarının gece manzarasını oluşturmak ve dönüştürmek için doğru planlanan aydınlatma tasarımına ihtiyaç duyarız. Gerçek ve sanal, estetik ve işlevsel arasındaki geçiş aydınlatma ile sağlanmaktadır. Kentin bazı kısımları, özellikle kent meydanları çeşitli aydınlatma stratejilerinin bir parçası haline gelmiştir (Bertin, 2015).

Aydınlatma master planları oluşturulurken, ilk adım tüm kentin analizi olmalıdır. Çünkü kenti ve kentliyi tanımak, hangi tür aydınlatma elemanı kullanılacağının en güzel cevabı olacaktır. Bunun yanı sıra kentli ve kente gelen misafirler gözünden kente bakıyor olmak, konfor ve estetik kavramlarına cevap verecek bir plan hazırlamada yardımcı olacaktır (Şerefhanoğlu Sözen, 2005: 13-16).

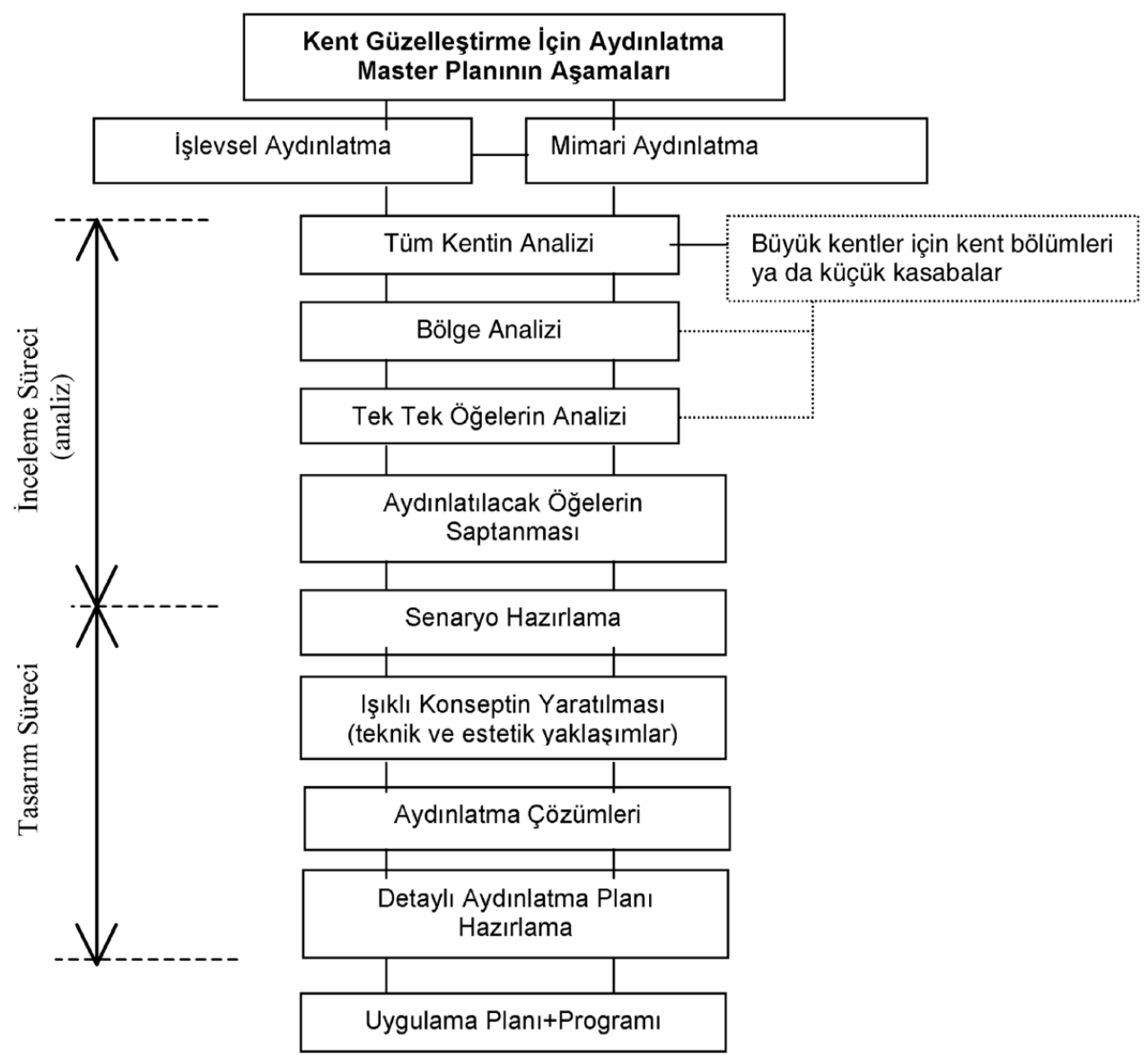

Şekil 2: Kent Güzelleştirme için Aydınlatma Master Plan Aşamaları (Şerefhanoğlu Sözen, 2005: 13).

\section{Ankara Beypazarı Örneği}

\subsection{Tarihi}

Beypazarı, İç Anadolu bölgesinde bulunan Ankara şehrine ait tarihi bir ilçedir. Roma döneminden itibaren İstanbul ve Bağdat' 1 birbirine bağlayan İpek yolu üzerindedir. Önemli bir ticari konuma sahip olan Beypazarı, bugüne kadar tarihi dokusunu korumayı başarmıştır. Bu tarihi doku, özellikle ahşap ve taş evlerin, cami ve hanların korunması ve civardaki doğal güzellikleriyle günümüzde halen önemli bir ziyaret merkezi olmaya devam etmektedir (Atak, 2008: 31-35). 


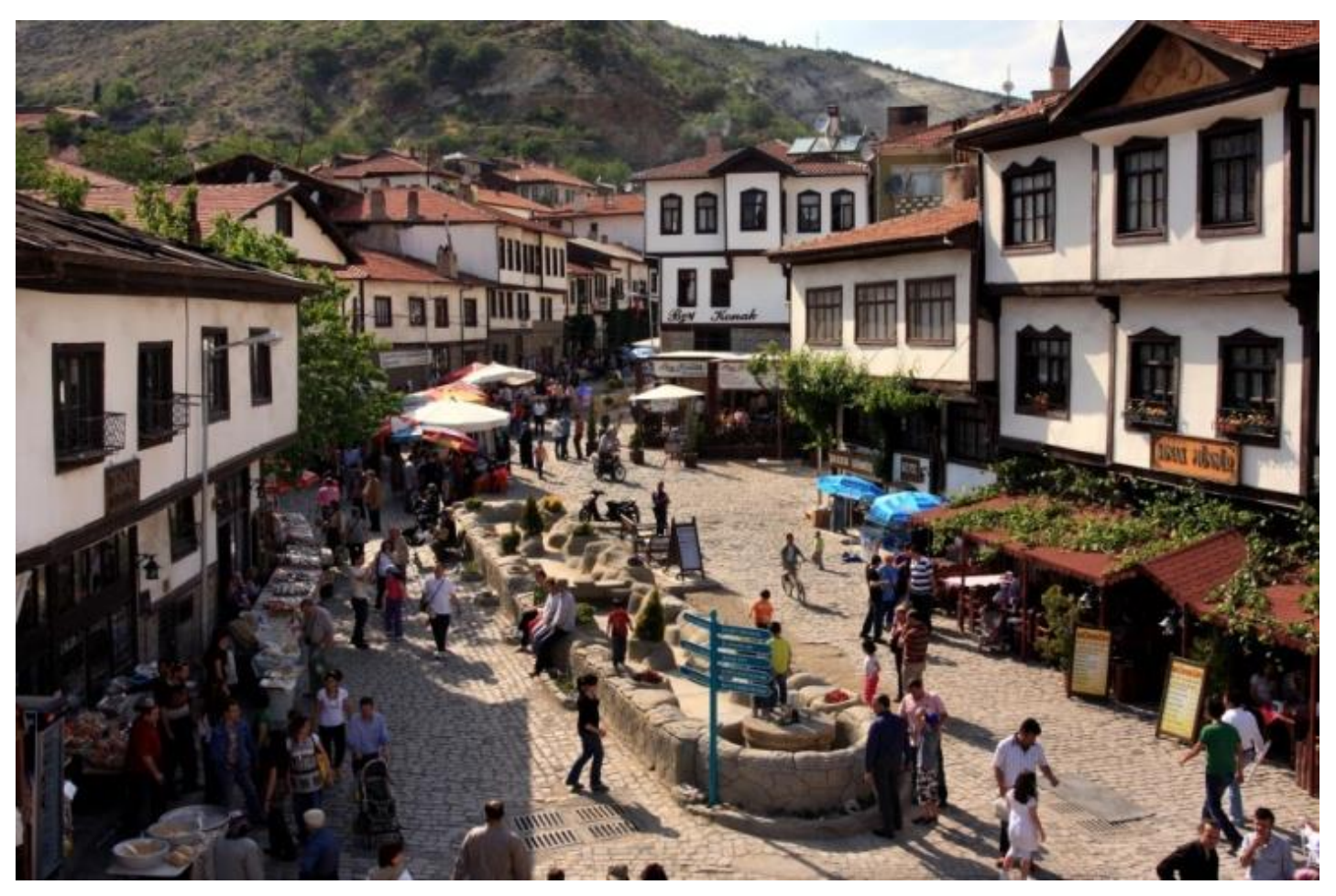

Şekil 3: Ankara Beypazarı'na genel bakış (URL-1)

\subsection{Mevcut Durum}

Beypazarının mevcut durumu incelendiğinde; İki-üç katlı yapıların yer aldığı tarihi bölgede şehrin dokusu ile örtüşmeyen, eski tip aydınlatma elemanları kullanılmıştır. Kullanılan aydınlatmalar 8-10m yüksekliğinde olup, insan ölçeği ve mevcut yapı yükseklikleriyle uyum göstermemektedir (Şekil 4). Konutların bulunduğu yerlerde yüksek aydınlatma elemanlarından yayılan ışık, kontrolsüz olarak yapılarda ışık işgaline neden olmuştur (Şekil 5).

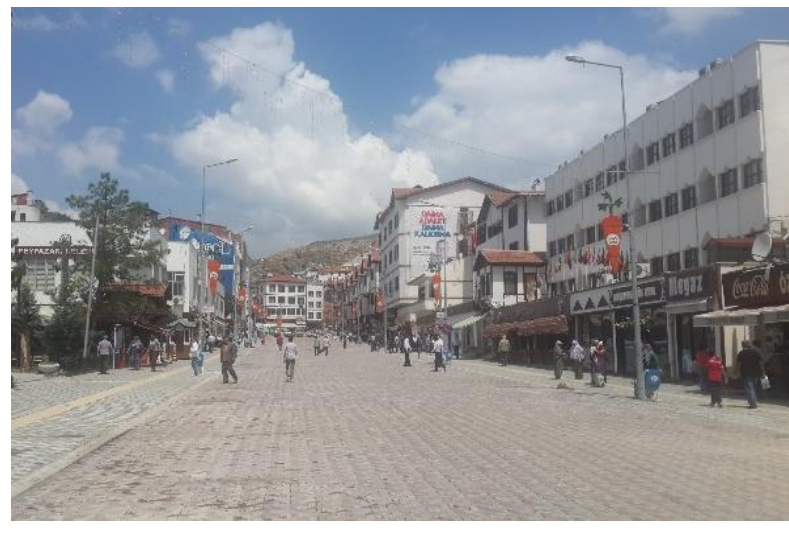

Şekil 4: Beypazarı meydan görünüm (Bade Kanatlı Arşivi)

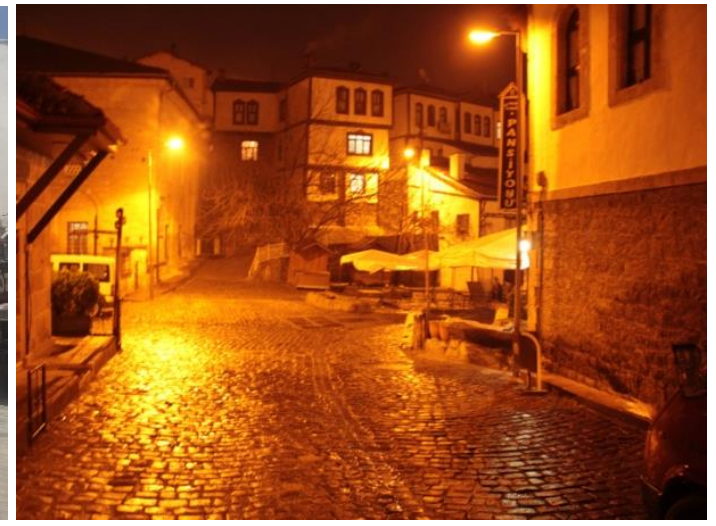

Şekil 5: Beypazarı gece görünüm (URL-2)

Ayrıca kentin dokusu ile örtüşmeyen aydınlatma elemanları bazı bölgelerde yetersiz kalmış, bazı bölgelerde ise farklı renk ışık kullanılmıştır (Şekil6). 

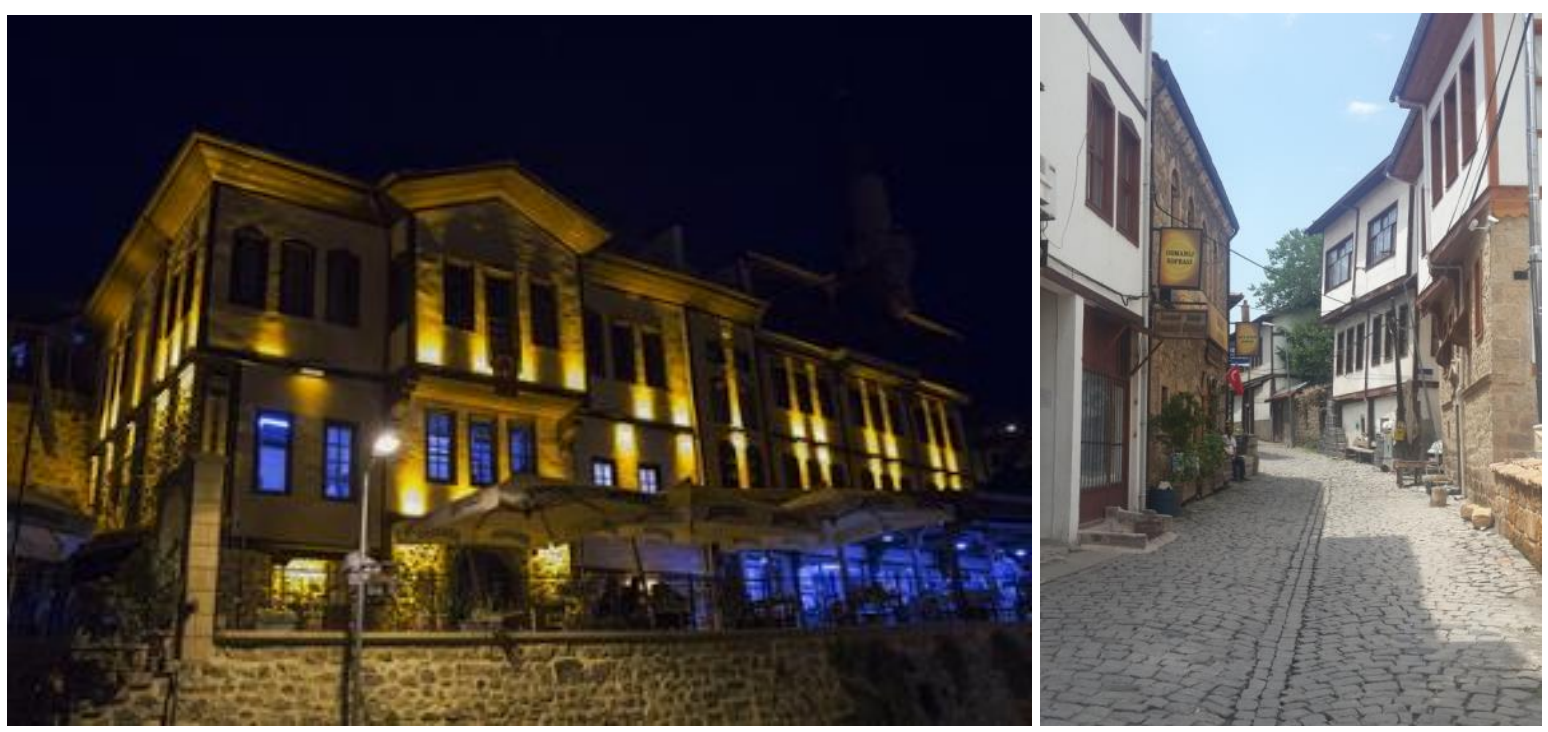

Şekil 6: Beypazarı- Tarihi Taş Mektep (URL-3)

Şekil 7: Beypazarı dar sokak görünüm (URL-4)

Şekil 7'de görüldüğü gibi bölgede çok fazla aydınlatılmamış sokak hakimdir. Bu durum arızalı armatürlerin yanı sıra hiç aydınlatma elemanı kullanılmayan sokaklar da görülmektedir. Işı̆ıı olmaması ya da yetersiz olması kentlinin hareketini kısıtlayacak, ayrıca güvenlik ve emniyetin sağlanmasını zorlaştıracaktır. Temel ihtiyaçların karşılanmaması yüzünden, kentlinin bölgeye ait olma düşüncesi, idrak etme ve estetik açıdan değerlendirmesi mümkün değildir.

\subsection{Planlama Yaklaşımı}

Tarihi Beypazarı Bölgesi'ni Maslow'un İhtiyaçlar Hiyerarşisi kapsamında incelediğimizde, insanı fizyolojik ve psikolojik anlamda olumsuz etkileyen ve kentin estetik ve tarihi dokusunu gölgeleyen bir aydınlatma görmekteyiz. Ancak, kent meydanındaki aydınlatma, tarihi doku ve insan ile uyumlu bir yaklaşım sergilemelidir. Dolayısıyla kentteki ihtiyaçlarımızın karşılanması ve konforumuz için kent aydınlatmalarının doğru bir planlamaya ihtiyacı vardır.

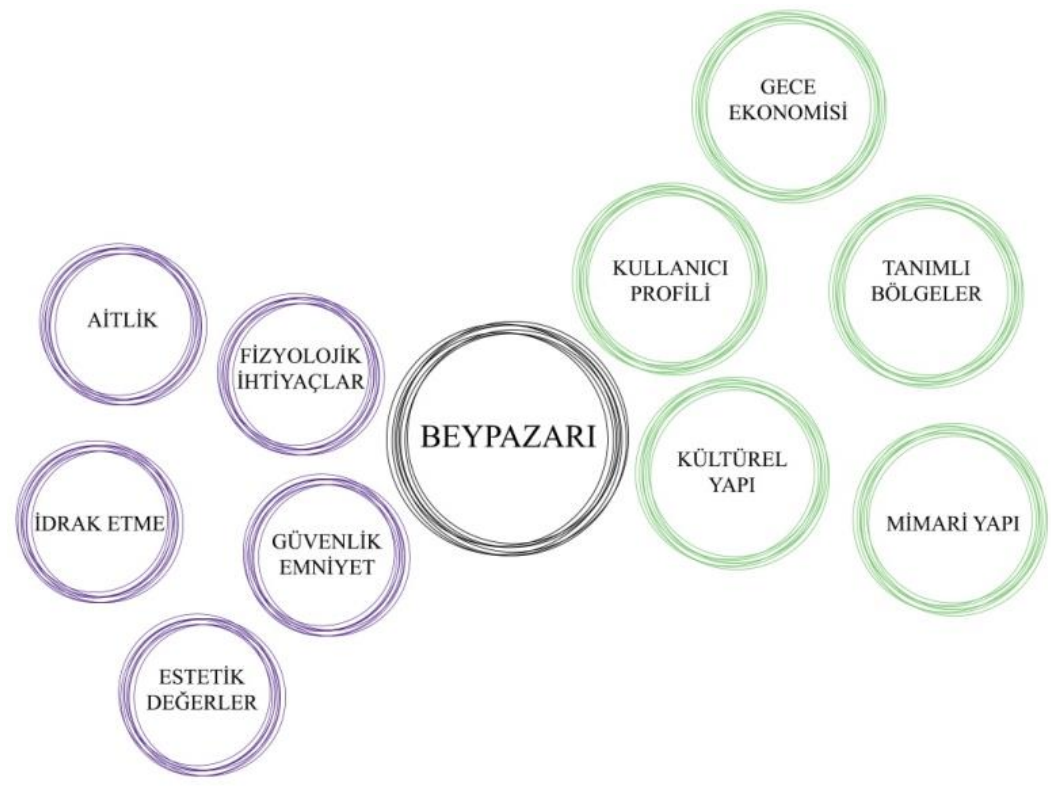

Şekil 8: Beypazarı bölgesi analiz şeması (Bade Kanatlı Arşivi)

Kentsel Aydınlatma Elemanlarının İnsan Odaklı Tasarım Kavramı Çerçevesinde Ankara Beypazarı Örneği Üzerinden İncelenmesi

Journal of Urban Academy | Volume: 14 Issue: 1 | ISSN: 2146-9229

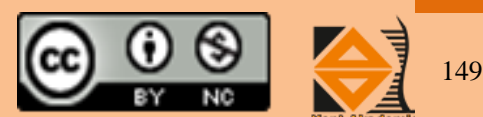




\section{4. Öneri}

Beypazarı meydanındaki aydınlatmaların analizi yapılırken, bu tarihi mekânın güzelliği ön plana çıkarılması amaçlanmış, ayrıca içinde bulunan mekânı ziyaret edecek kişilerin konforu göz önüne alınmıştır. Yeniden düzenlemede mekândaki tarihi dokuya dokunulmamıştır. Aydınlatma planı düzenlenirken, meydana çıkan tüm sokak ve caddeler birlikte planlaması gerektiği düşünülmüştür. Aydınlatma direklerini mümkün olduğu kadar korumaya ve yer değiştirilmeye çalışılarak bir düzenleme yapılması sağlanmıştır.

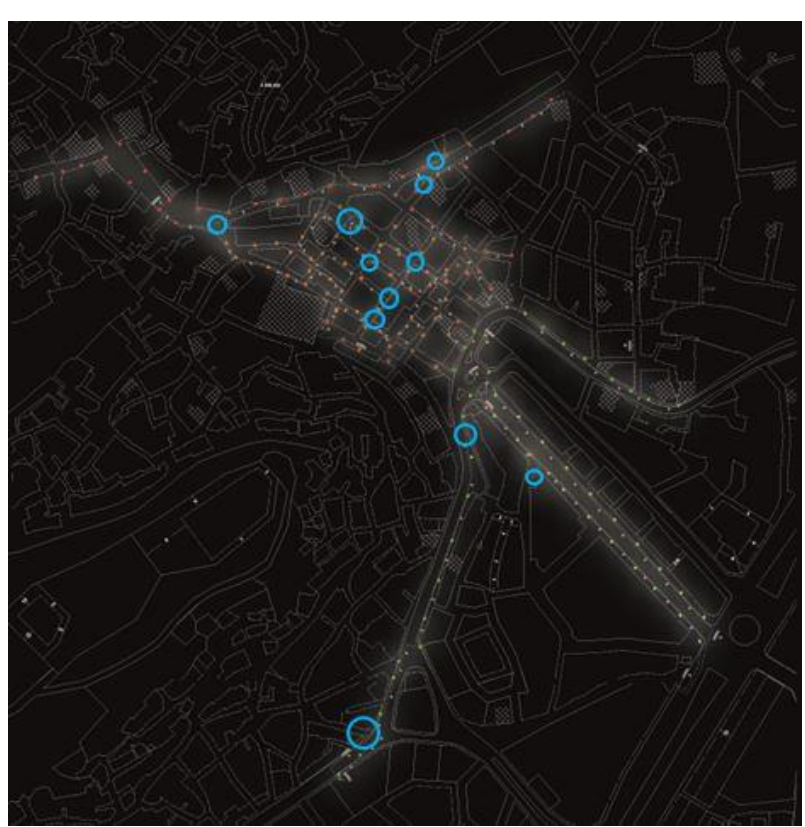

Şekil 9: Aydınlatma elemanları mevcut durumu (Bade Kanatlı Arşivi)

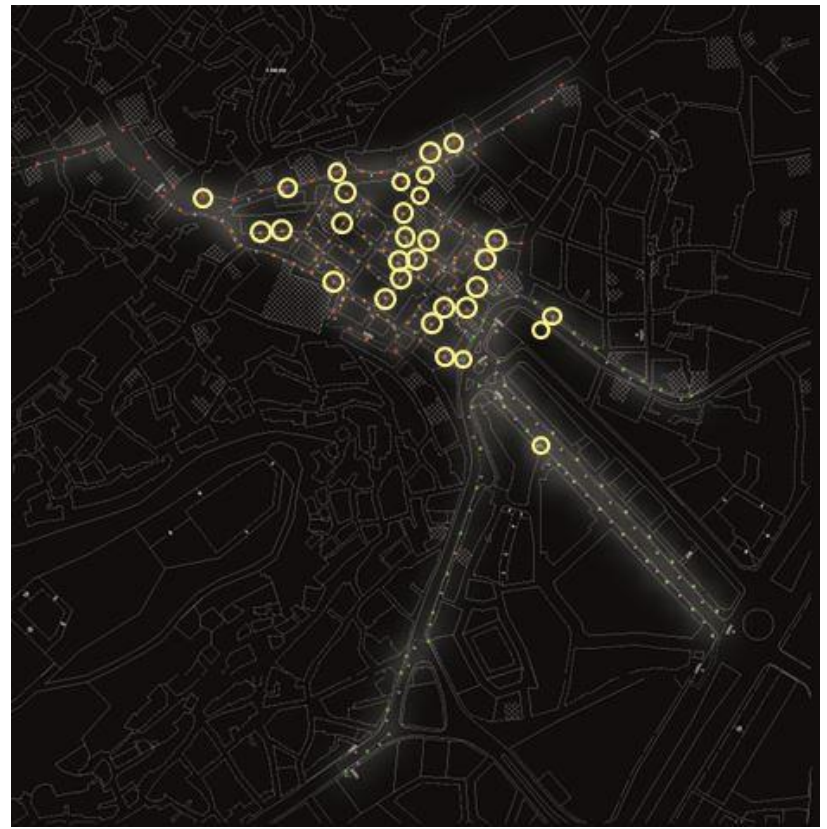

Şekil 10: Aydınlatma elemanları önerilen durum (Bade Kanatlı Arşivi)

Mevcut durum aydınlatma planında bulunan 11 adet aydınlatma elemanı çıkarılması öngörülmüştür (Şekil 9). Ayrıca mevcut aydınlatma planında olmayan 31 adet aydınlatma elemanı eklenmesi öngörülmüştür (Şekil 10).
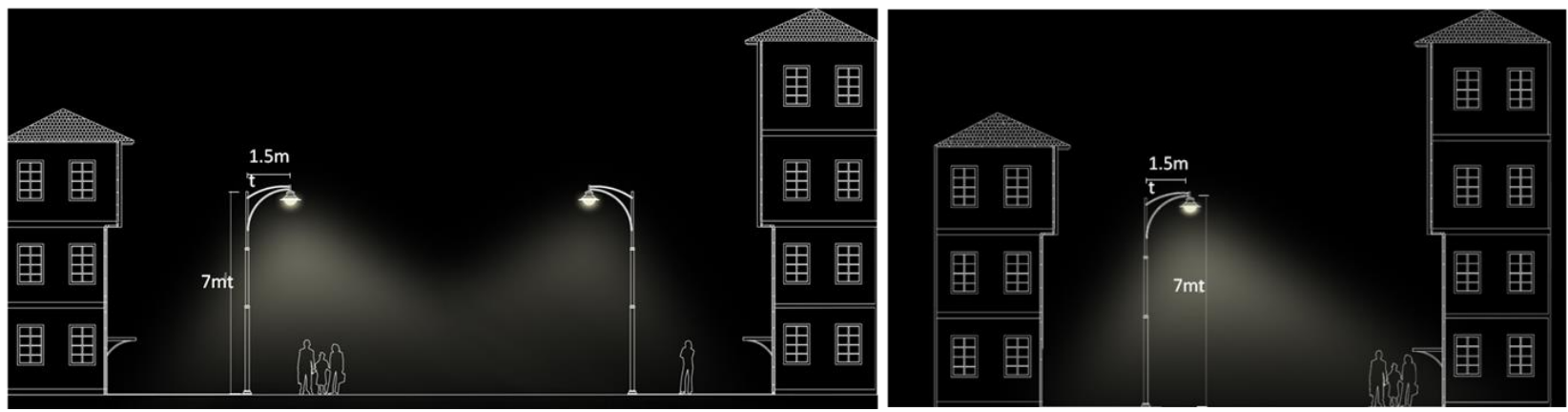

Şekil 11: Cadde örnekleri için prensip kesit (Bade Kanatlı Arşivi)
Şekil 12: Geniş sokak örnekleri için prensip kesit (Bade Kanatlı Arşivi)

Ana caddelerde ve geniş tarihi sokaklarda tek konsollu 7 metre yüksekliğinde aydınlatma direği kullanılması öngörülmektedir. Sokağın genişliğine ve insanın temel ve üst düzey ihtiyaçlarına göre tek sıra (Şekil 11) ya da karşılıklı iki sıra (Şekil 12) halinde dizilim yapılacaktır. 


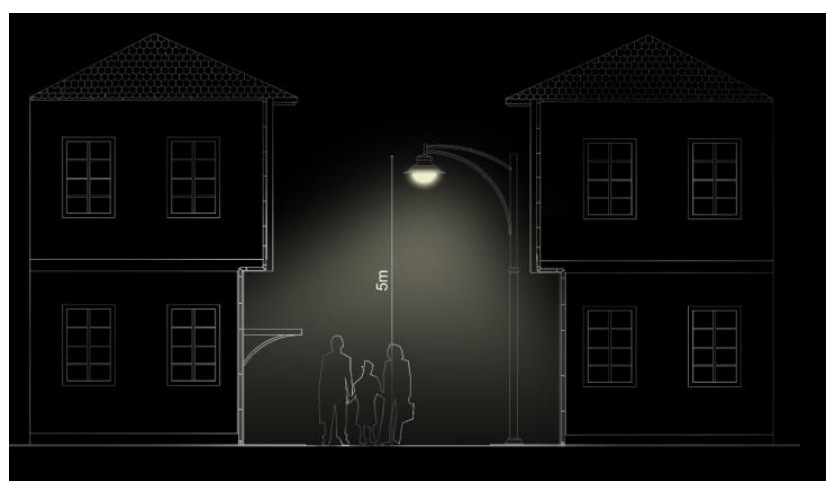

Şekil 13: Dar sokak örnekleri için prensip kesit 1 (Bade Kanatlı Arşivi)

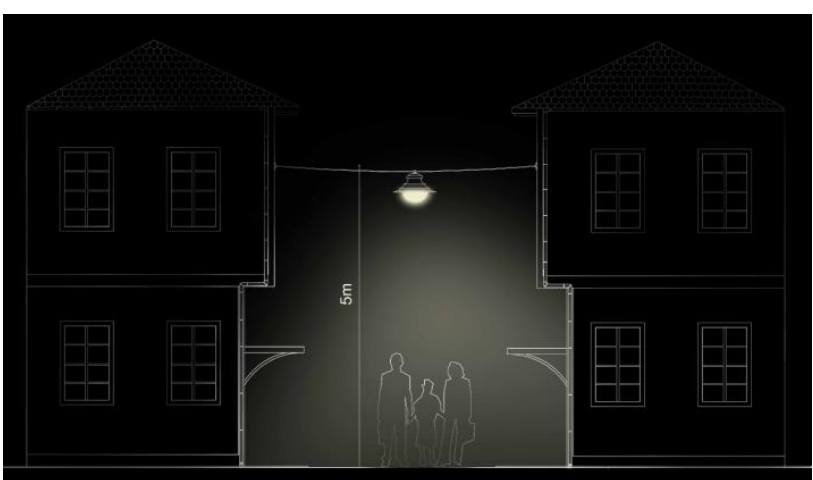

Şekil 14: Dar sokak örnekleri için prensip kesit 2 (Bade Kanatlı Arşivi)

Tarihi dar sokaklarda ise 5 metre yüksekliğinde tek konsollu aydınlatma direği kullanılması öngörülmektedir (Şekil 13). Ayrıca bazı dar sokaklarda, 5 metre kotunda katener aydınlatma sistem yerleşimi öngörülmektedir (Şekil 14).

\subsection{Abraham Maslow'un İhtiyaçlar Hiyerarşisi Kuramı Kapsamında Mevcut Durum ve Öneri Planının Karşılaştırılması}

Tarihi Ankara Beypazarı Bölgesi'nin kent aydınlatmasının mevcut durumu ve ortaya konulan öneri planı Maslow'un İhtiyaçlar Hiyerarşisi bağlamında incelenmiş ve karşılaştırılması aşağıdaki Tablo 2'de verilmiştir.

\section{Maslow'un İhtiyaçlar Hiyerarşisi Basamakları}

Fizyolojik İhtiyaçlar

Güvenlik İhtiyacı

Ait Olma Duygusu

\section{Mevcut Aydınlatma}

Hareket insanın temel ihtiyaçlarından biridir. Aydınlatma elemanlarının yetersizliği ya da bakımsızlığından kaynaklı işlevsizliği nedeniyle, sokakların gecenin karanlığında kaybolması, insan hareketini kısitlanmaktadır. $\mathrm{Bu}$ durum temel basamağın karşılanmadığını bize göstermektedir.

*Maslow'a göre; temel gereksinimler karşılanmadığ 1 sürece, diğer ihtiyaçlardan söz etmek mümkün değildir.

Karanlık, insan psikolojisi üzerinde korku hissini oluşturmaktadır. Korku hissi beraberinde güvenlik ihtiyacını sorgulamayı gerektirir. Yetersiz ya da hiç aydınlatma elemanı bulunmayan sokakların güvenliğinden ise söz etmek mümkün değildir. Yetersiz ya da hiç aydınlatılmamış sokakların mevcut olmasindan dolayı, güvenlik ihtiyacının karşılanmadığı gözlemlenmiştir.

Bazı bölgelerde yetersiz aydınlatılmış sokakların olması sebebiyle, gecenin karanlığında sosyal hayatın devam etmediği

\section{Önerilen Aydınlatma}

Aydınlatma elemanlarının homojen olarak tarihi bölgeye dağıtılması, insan hareketinin gece de kesintisiz devam etmesini sağlamaktadır. Bu durum insanın temel ihtiyacinı karşılamakta ve bir sonraki basamağa geçmesini mümkün kılmaktadır.

Tarihi bölgede, bozuk armatürlerin tamiri, eksik veya fazla olduğu tespit edilen aydınlatma elemanlarının eklenmesi veya çıarılması ile gündüz doğal ışıkla sağlanan konforun geceye de aynı şekilde yansıması, bölgenin güvenliği açısından önem taşımaktadır.

Tarihi bölgede insanı odağına alarak aydınlatma planlaması yapıldığg $\quad$ zaman, kenti 


\section{İdrak Etme İhtiyacı}

\section{Estetik İhtiyaçlar}

görülmüştür. $\mathrm{Bu}$ durum, insanın yaşadığ 1 bölgede ait olma duygusunu sorgulamaya yol açmaktadır.

Yapı ölçeği ile uyumlu olmayan aydınlatma elemanlarından yayılan kontrolsüz 1şıklar, insanın idrak etme ihtiyacını karşılamasını önlemektedir.

Tarihi doku ile uyumlu olamayan aydınlatma elemanlarının kullanılması ve farklı renk 1şık seçimleri dolayısıyla, estetik ihtiyaçların karşılanmadığı gözlenmiştir. deneyimleyen kişilerin sosyal hayattaki devamlılığ 1 kesintisiz ve kent ile bir bütün olarak devam ettiği gözlemlenmiștir. Bu bütünlük ise ait olma duygusunu beraberinde getirmektedir.

Yap1 ölçeği ile uyumlu aydınlatma elemanlarının seçimi ve ışı̆̆ın kontrollü yayılımı, insandaki idrak etme ihtiyacını karşılamaktadır.

Tarihi dokuya uygun, aydınlatma elemanlarının seçilmesi ve aynı renk 1şı seçimi, insandaki estetik ihtiyacı karşılamaktadır.

Tablo 2: Ankara Beypazarı Bölgesi'nin Maslow'un İhtiyaçlar Hiyerarşisi kapsamında mevcut durum ve öneri planının karşılaş̧ırılması (Bade Kanatlı ve Cem Doğan tarafından hazırlanmıştır.)

\section{SONUÇ:}

1960'lı yıllarda Abraham Maslow tarafindan ortaya konulan İhtiyaçlar Hiyerarşisi kuramı, günümüzde halen kabul edilmektedir. İhtiyaçlar Hiyerarşisi kuramı incelendiğinde, fizyolojik ihtiyaçlar ve güvenlik ihtiyacı basamaklarının, insandaki temel ihtiyaçlar olduğunu söylemek mümkündür. Temel ihtiyaçlar, biyolojik yani güdüsel olarak insanda var olduğu ve bu ihtiyaçların sağlıklı bir insan hayatı için kısa aralıklarla sürekli olarak karşılanması gerektiği bilinmektedir. Çevresel faktörlere göre değişiklik gösterebileceğini söylediği diğer basamaklar olan; ait olma ihtiyacı, idrak etme ihtiyacı ve estetik ihtiyaçların karşılanması halinde ise, insan kendini bulmayı tamamlamaktadır. Dolayısıyla, insanın ihtiyaçlarını anlayabiliyor olmak, insanı anlamaktır. İhtiyaçlar Hiyerarşisi kuramı neredeyse bir asır önce ortaya konmuş olmasına rağmen, bugün bile insanın olduğu her konuda bize yol göstermektedir. Çünkü insan bu süreçte değiş̧medi; değişen insanın çevresiydi. Dolayısıyla insanın bulunduğu her konuda bir fikir ortaya koyarken ya da bir tasarım yaparken, doğru ve hızlı bir sonuca ulaşmak için, izlenecek yöntemin odağına insan kavramını almak gerekmektedir. Maslow'un İhtiyaçlar Hiyerarşisi kuramı, insanın konu edildiği her alanda doğru bir şemadır. Çünkü odağında insan kavramını bulundurmaktadır. Ortaya koyduğu basamaklar ise, doğru bir tasarım anlayışı için bize yol gösterecek olan maddelerdir. Maslow'a göre bu maddeler; fizyolojik ihtiyaçlar, güvenlik ihtiyacı, ait olma ihtiyacı, idrak etme ihtiyacı ve estetik ihtiyaçlar olmak üzere hiyerarşik olarak karşılanması gerekmektedir. İhtiyaçlar hiyerarşik olarak karşılanmadığı sürece, bir diğer basamağa geçmek mümkün değildir.

Günümüzde kentlerin doğru bir şekilde aydınlatılması için, aydınlatma master planları ortaya konulmaktadır. Şerefhanoğlu Sözen'in ortaya koyduğu "Kent Güzelleştirme için Aydınlatma Master Plan Aşamaları" şeması bunlardan biridir. $\mathrm{Bu}$ şema incelendiğinde, içindeki maddelerin insan ihtiyaçları çerçevesinde ortaya konulduğunu söylemek mümkündür. Kent için ortaya konulan aydınlatma master planları, işlevsel ve estetik açıdan kentli ve kente gelen misafirlerin ihtiyaçlarını karşılamaya yöneliktir. Çünkü insan, bulunduğu ortamı kendi ihtiyaç ve konforuna göre düzenler. $\mathrm{Bu}$ bağlamda, kent aydınlatmasını düzenlemek için ortaya konulan master plan aşamalarının, Maslow'un İhtiyaçlar Hiyerarşisi kuramının bir yansıması olduğunu söyleyebiliriz.

Bu çalışmada, tarihi Ankara Beypazarı Bölgesi'ndeki aydınlatma elemanlarının mevcut durumu, Maslow'un İhtiyaçlar Hiyerarşisi kuramı kapsamında ortaya koyduğu maddeler üzerinden incelenmiş ve insan odaklı tasarım kavramının dikkate alınmadı̆̆ 1 sonucuna varılmıştır. Kent aydınlatmasındaki eksiklikler ve yanlış uygulamalar nedeniyle bölgede yaşayan insanların ve tarihi bölgeyi ziyarete gelen misafirlerin, gece çeşitli sorunlar yaşadığı bilinmektedir. Bu sorunlar temelinde, tarihi bölgenin aydınlatılmasının odağına insan kavramının konulmadığını göstermektedir. Ancak tarihi bölge için ortaya konulan yeni öneride, kesintisiz bir gece yaşamının insanın sosyal hayatında bir yeri olmasına olanak sağladığını ve gündüz gibi gece de şehir hayatındaki tüm ihtiyaçlarını konforlu bir şekilde sağladığı sonucuna varılmıştır. 
Maslow’un İhtiyaçlar Hiyerarşisi kuramını Ankara Beypazarı örneğinde kentsel aydınlatma elemanları çerçevesinde incelendiğinde, tüm kent aydınlatmaları için bir öneri planı ortaya sunmak mümkündür. Bu öneri planı hiyerarşik olarak takip edildiğinde, doğru bir kentsel aydınlatma planının ortaya konulması mümkündür.

\section{Fizyolojik İhtiyaçlar}

Güvenlik İhtiyacı

Ait Olma İhtiyacı

İdrak Etme İhtiyacı

Estetik İhtiyaçlar
Aydınlatma elemanlarının homojen olarak bölgede konumlandırılması, gece insan hareketinin kesintisiz devamını sağlamaktadır.

Bozuk, eksik veya fazla olan aydınlatma elemanlarının; tamir edilmesi, eklenmesi veya çıkarılması ile bölgede yeterli bir aydınlatma sağlanıp, güvenlik ihtiyacı karşılanmalıdır.

Gece de gündüz gibi, sosyal hayatın devamlılığı açısından, bölgede yeterli sayıda aydınlatma elemanı kullanılması gerekmektedir.

Işığın kontrollü yayılması insan algısı açısından önemli olduğu için, aydınlatma elemanları seçilirken yüksekliğin yapı ölçeği ile uyumlu olmasına dikkat edilmesi gerekmektedir.

İnsandaki estetik ihtiyacın karşılanması, bölgeye uygun aydınlatma elemanın seçilmesi ve doğru renk 1şık kullanımıyla karşılanacaktır.

Tablo 3: İnsan ihtiyaçlarını karşılayan bir kentsel aydınlatma planlaması için uyulması gereken maddeler (Bade Kanatlı ve Cem Doğan tarafından hazırlanmıştır.)

Bu planlamaya uyulması halinde;

- Fizyolojik İhtiyaçlar: Gece boyunca insan hareketinin kesintisiz devam etmesine olanak sağlamaktadır.

- Güvenlik İhtiyacı: İnsanın gece karanlığında karşıdan gelenin yüzünü açıkça görebilmesini ve dolayısıyla kendini güvende hissetmesini sağlamaktadır. Aynı zamanda karanlığın getireceği her türlü suçtan insanı korumayı amaçlamaktadır.

- Ait Olma İhtiyacı: Gündüz gibi gecede insanın sosyal hayatının devam ediyor olması, kente dair aitlik hissini sağlamaktadır.

- İdrak Etme İhtiyacı: Kentin tarihi dokusunu okumayı ve anlamayı sağlar. Ayrıca gece boyunca insandaki yer-yön kavramının devamlılı̆̆ını sağlar.

- Estetik İhtiyaçlar: Güzel olan her yerde insan kendini bulur, kendini tanır ve kendine ulaşır. Aslında bu basamak, tüm diğer ihtiyaçların tamamlanmasıdır.

Sonuç olarak; insan kavramı tasarımın odağında olmalıdır. Çünkü kent için yapılan her mobilya, aslında insanın kent hayatındaki konforu için yapılmaktadır. Dolayısıyla, insanı odağına almayan hiçbir tasarımın başarılı olması mümkün değildir. Maslow'un İhtiyaçlar Hiyerarşisi kuramının ise, kamusal alanlar için tasarlanan kent mobilyalarının insan odaklı tasarım çerçevesinde bize doğru bir yol çizeceğini söyleyebiliriz.

\section{Etik Standart ile Uyumluluk}

Çıkar Çatışması: Yazarlar herhangi bir çıkar çatışmasının olmadığını beyan eder.

Etik Kurul İzni: Bu çalışma için etik kurul iznine gerek yoktur.

Finansal Destek: Yoktur. 


\section{KAYNAKÇA:}

\section{Tezler}

Akkaya, M. (2019). Kentsel Tasarım Kapsamında Zamanın Mekân Algısı Üzerine Etkileri, Yüksek Lisans Tezi, Ankara Üniversitesi Fen Bilimleri Enstitüsü Peyzaj Mimarlığı Anabilim Dalı, Ankara, Sayfa: 3- 120.

Atak, S. (2008). Beypazarı Şehri’nin Kuruluşu, Gelişimi ve Şehir İçi Arazi Kullanımı, Yüksek Lisans Tezi, Ankara Üniversitesi Sosyal Bilimler Enstitüsü Coğrafya (Türkiye Coğrafyası) Anabilim Dalı Ankara, Sayfa: 31-35.

Aydın, O. (2015). Tralleis Batı Nekropolü Kandil Buluntuları, Yüksek Lisans Tezi, Adnan Menderes Üniversitesi Sosyal Bilimler Enstitüsü Arkeoloji Anabilim Dalı, Sayfa:10-23.

Genamaz, S. (2008). Kentsel Mekân Algsında Yapay Aydınlatmanın Kullanılması ve Kent İmajı ile İlișkilendirilmesi, Yüksek Lisans Tezi, Yıldız Teknik Üniversitesi, Fen Bilimleri Enstitüsü Şehir ve Bölge Planlama Anabilim Dalı, Kentsel Mekân Organizasyonu ve Tasarımı Programı, İstanbul.

Küçük, P. (2014). Kentsel Aydınlatmada, Aydınlatma Master Planları ve Aydınlatma Master Planları İçin Bir Rehber Önerisi, Yüksek Lisans Tezi, İstanbul Teknik Üniversitesi Fen Bilimleri Enstitüsü Kentsel Tasarım Anabilim Dalı, İstanbul, Sayfa: 5, 13, 57.

Küçükkılıç, E. (2008). Kent Mobilyası Olarak Aydınlatma Elemanları - Boğaziçi’nden Örnek İncelemeler, Yüksek Lisans Tezi, Yıldız Teknik Üniversitesi, Fen Bilimleri Enstitüsü Mimarlık Anabilim Dalı, Yapı Fiziği Programı, Sayfa:2-14.

Onuk, N. T. (2008).Kentsel Dış Mekânların Aydınlatılması Kapsamında Işık Kirliliğinin İrdelenmesi, Yüksek Lisans Tezi, İstanbul Teknik Üniversitesi Fen Bilimleri Enstitüsü, Peyzaj Mimarlığı Anabilim Dalı, İstanbul.

Zeybek Çetin, R. (2012). Tarihi Kent Merkezlerinde Yeniden Canlandırma Politikaları Üzerine Değerlendirme: İzmir Kemeraltı Örneği, Yüksek Lisans Tezi, Dokuz Eylül Üniversitesi Fen Bilimleri Enstitüsü Şehir ve Bölge Planlama Bölümü Kentsel Tasarım Anabilim Dalı, İzmir, Sayfa:41.

\section{Makaleler ve Bildiriler}

Bertin, S. (2015). A Reflection on Light as a Medium: Surveillance, the Sublime, and Poetics in Montreal's Nocturnal Landscape, Ph.D. Candidate in Environmental Design, University of Montreal, Intermédialités Dergisi, Çevrimiçi Yayın: 30 Ağustos 2016, Sayı:26.

Çağlayan, S. A. , Özturan, Ö., \& Erten Bilgiç, D., (2014). Kent Meydanı Yapay Aydınlatması Kriterleri. 1.Uluslarası Kentsel Planlama, Mimarlık, Tasarım Kongresi, Kocaeli. Cilt.1,Sayfa:.417-426.

Düzenli, T., Yılmaz S., Özkan D.G., (2017). Peyzaj Mimarlığı Eğitiminde Donatı-Mekân İlişkisinin Kurgulanması Building The Relaiionship Between Furniture- Space In The Education of Landscape Architecture, The Journal of International Social Research, 10: 478- 485.

Fiori, S. and Regnault C. (2007). La conception des ambiances, Concepteurs sonores et concepteurs lumière. Figures professionnelles émergentes des ambiances architecturales et urbaines, Culture et recherche, No:113, Page:19-21.

Güneş, S. (2005). Kent Mobilyası Tasarımından Disiplinlerarası Etkileşim, Planlama- TMMOB Şehir Planlamacıları Odası Yayını 2005/3, Sayı:33: 92-95.

Kılıç Sirel, H. (2016). Türkiye Tasarım Kronolojisi- Aydınlatma, 3. İstanbul Tasarım Bienali: Biz İnsan Mıyız? Kapsamında hazırlanmıştır.

Köseli, C. G. Ve Yener, A.K. (2019). İnsan Odaklı Aydınlatma Tasarım Konsepti: Ofis İç Mekânı İçin Bir Öneri, 12. Aydınlatma Kongresi Bildiriler, 18-19 Eylül 2019 İstanbul Fuar Merkezi İstanbul, Sayfa: 145-152. 
Özer, N. M. ve Ayten, A. M. (2005). Kamusal Odak Olarak Kent Meydanları, Planlama- TMMOB Şehir Planlamacıları Odası Yayını, Journal of the Chamber od City Planners- Union of Chambers of Turkish Engineers and Architects 2005/3, Say1:33 Sayfa:96-98.

Özenç, S. ve Menteşeoğlu, D. (2013). İzmir'deki Kent Aydınlatmasına Yönelik Olumsuz Uygulamalar ve Çözüm Önerileri, TMMOB 2. İzmir Kent Sempozyumu / 28-30 Kasım 2013, Sayfa:69-73.

Özömer, M. ve Sümengen, Ö. (2019). Kültür Varlıklarının Dönüşümü ile Sokak Ölçeğinde Aydınlatma Tasarımı Değerlendirmesi: Kayseri-Ali Saip Paşa Sokağı, 12. Aydınlatma Kongresi Bildiriler, 18-19 Eylül 2019 İstanbul Fuar Merkezi İstanbul, Sayfa: 105- 112.

Şerefhanoğlu Sözen, M. (2005). Kent Güzelleştirme ve Aydınlatma Master Planı, TMMOB Elektrik Mühendisleri Odası, III. Ulusal Aydınlatma Sempozyumu ve Sergisi Bildirileri, Y.T.Ü., Mimarlık Fakültesi, İstanbul, Sayfa:13.

\section{Raporlar}

ISO 9241-210:(2010). Ergonomics of Human-System Interaction, Part 210: Human-Centred Design for Interactive Systems, 2010.03.15, Page:4.

\section{Kitaplar}

Lynch, K. (1960). The Image Of The City, Kent İmgesi, Massachuselts Institlite Of Technology \&Harvard College, Çeviren: İrem Başaran Türkiye İş Bankası Kültür Yayınları, IV. Basım: Kasım 2012, Sayfa:3-14.

Maslow, H. A. (1954). Motivation and Personality, Harper and Row, New York. Page:59-75

Maslow, A. (1962). Toward A Psychology of Being, İnsan Olmanın Psikolojisi, Çeviren: Okhan Gündüz, Kural Dışı Yayıncılık, İstanbul Mart 2001, Sayfa:26, 162-165.

Narboni, R. (2004). Lighting the Landscape: Art, Design and Technologies, Birkhäuser, Germany, Page:66.

\section{Web Siteleri}

URL-1. https://gezimanya.com/beypazari (Erişim Tarihi: 2020.05.22).

URL-2. https://kuvvetlitabanlar.com/beypazari/ (Erişim Tarihi: 2020.11.01).

URL-3. http://www.hasankoca.com.tr/beypazari/ (Erişim Tarihi: 2020.11.01).

URL-4 https://kuvvetlitabanlar.com/beypazari/ (Erişim Tarihi: 2020.11.01). 